\title{
Mass spore production and inoculation of Calonectria pteridis on Eucalyptus spp. under different environmental conditions
}

\author{
Rafael F. Alfenas ${ }^{1,2}$, Olinto L. Pereira ${ }^{1}$, Rodrigo G. Freitas ${ }^{1}$, Camila S. Freitas ${ }^{1}$, Miguel A.D. Dita ${ }^{3}$ \& \\ Acelino C. Alfenas ${ }^{1}$ \\ ${ }^{1}$ Departamento de Fitopatologia, Universidade Federal de Viçosa, Viçosa, MG, 36570-000, Brazil; ${ }^{2}$ Clonar - Resistência a \\ Doenças Florestais, CENTEV, Viçosa, MG, 36570-000, Brazil; ${ }^{3}$ Bioversity International CATIE, Turrialba, 30501, Costa \\ Rica
}

Author for correspondence: Olinto L. Pereira, e-mail: oliparini@ufv.br

\begin{abstract}
Calonectria pteridis is one of the most important causal agents of Calonectria leaf blight (CLB) of Eucalyptus spp. in Brazil, which is a limiting factor for growth of Eucalyptus plantations. In this study we developed standard procedures for in vitro mass spore production and inoculation of $C$. pteridis for screening plant species and clones for resistance to CLB. The isolates used in this study were identified using similarity in DNA sequence to reference strains. Among six media tested, glucose asparagine agar induced the highest sporulation production and a significantly enhanced sporulation was found by scraping the aerial mycelium and temporarily submersing the cultures in tap water, followed by drying and additional incubation of the culture. We also demonstrated that the severity of CLB on excised leaves of two Eucalyptus spp. clones increased significantly when the inoculated leaves were incubated in the dark. The optimal temperature for infection was $26^{\circ} \mathrm{C}$ when plants were incubated for 48 hours post-inoculation in a mist chamber and then maintained in a greenhouse $\left(25^{\circ} \mathrm{C} \pm 5^{\circ} \mathrm{C}\right)$ for 50 days. This study identifies environmental conditions to improve spore production and inoculation procedures of $C$. pteridis for selection of resistant Eucalyptus spp.
\end{abstract}

Key words: Cylindrocladium, forest pathology, Hypocreales, leaf blight, sporulation

\section{INTRODUCTION}

Calonectria leaf blight (CLB), caused by Calonectria pteridis Crous, M.J. Wing. \& Alfenas (anamorph = Cylindrocladium pteridis Wolf), is one of the major foliar diseases of eucalyptus plantations grown in hot and humid regions in Brazil (Ferreira et al., 1995; Alfenas et al., 2009). Although CLB can also be caused by several Calonectria spp. (Chen et al., 2011; Alfenas \& Ferreira, 1979), C. pteridis is apparently the most common species associated with eucalyptus trees in Brazil (Alfenas \& Ferreira, 1979, Alfenas et al., 1979). Leaf blight lesions caused by $C$. pteridis are initially small (1- to 7-mm diameter), round or elongated, and light gray in color progressing to light-brown (Figure 1) (Ferreira et al., 1995). In highly susceptible genotypes, a large surface area of the leaf can become necrotic, followed by premature defoliation (Alfenas, 1986; Ferreira et al., 1995) (Figure 1). Although the total losses caused by CLB in eucalyptus plantations has not been precisely quantified, it is well accepted that $C$. pteridis significantly reduces plant growth by decreasing photosynthetic area due necrotic lesions and heavy defoliation caused by CLB (Alfenas et al., 2009; Graça et al., 2009). Because of the potential losses associated with CLB in eucalyptus plantations, control measures are needed to reduce CLB damage on eucalyptus trees. Although other control methods have been reported (Ferreira et al., 2006; Crous, 2002; Phipps, 1990), the planting of resistant genotypes is considered the most effective and economic method for disease control in the field (Crous, 2002; Alfenas et al., 2009). However, C. pteridis typically does not sporulate well in culture (Crous \& Wingfield, 1994), so it has been difficult to produce enough inoculum for resistance screening. Thus, simple and efficient procedures are needed for routine production of conidial inoculum in sufficient quantities to apply in mass selection of resistant genotypes of Eucalyptus spp. under controlled conditions. Although recent studies on penetration mechanisms and disease assessment of C. pteridis have been conducted by Graça et al. (2009), information was previously unavailable on the optimal conditions for mass spore production and artificial inoculation of this pathogen. Thus, the objective of this paper was to develop a standard protocol for mass spore production and inoculation of $C$. pteridis on Eucalyptus spp. under controlled environmental conditions to facilitate the screening programs for resistance to CLB.

\section{MATERIAL AND METHODS}

\section{Isolation and identification of the fungus}

Leaves showing symptoms of blight and soil samples were collected in commercial plantations of 

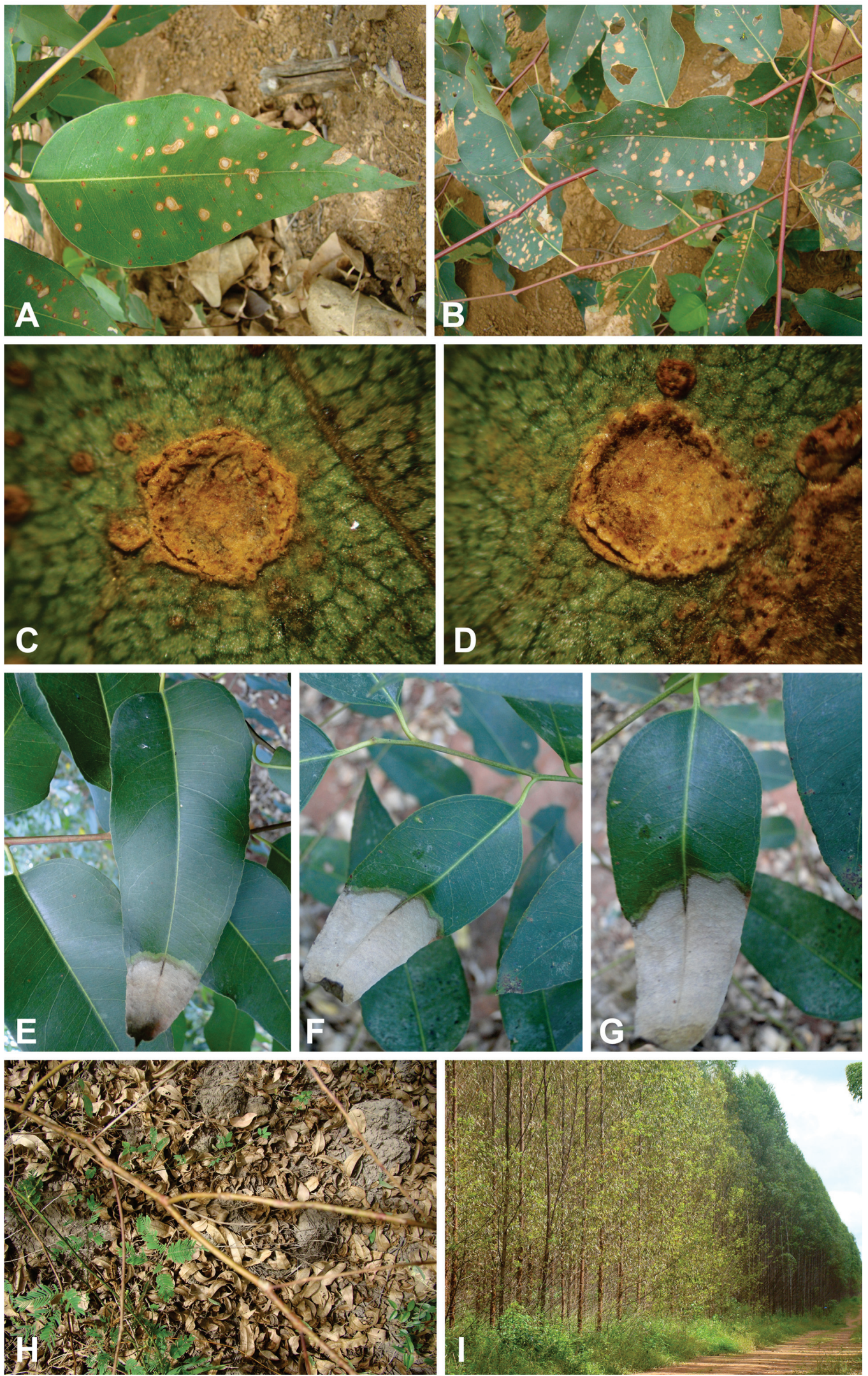

FIGURE 1 - Leaf blight and defoliation of Eucalyptus spp. caused by Calonectria spp. A,B. Small and rounded lesions caused by Calonectria pteridis. C,D. Rounded lesions surrounded by callus, usually containing sporulation only at the early stages of infection. E-G. Large lesions induced by other species of Calonectria. H. Defoliation. I. Susceptible (front) and resistant (back), Eucalyptus clones to Calonectria spp. leaf blight. 
Eucalyptus grandis $\times$ E. urophylla ("urograndis") hybrid clones in Monte Dourado (state of Pará), Açailândia (state of Maranhão), and Teresina (state of Piauí), Brazil.

To obtain single-spore cultures, conidial masses observed under dissecting microscope were placed in a Petri dish (90 mm diameter) containing water agar medium [WA; $1.5 \%(\mathrm{w} / \mathrm{v})$ agar, Vetec]. Immediately following, $2 \mathrm{~mL}$ sterile distilled water (SDW) were added to the WA plates. The SDW was dispersed by hand shaking, and excess of water was removed by inverting the Petri dishes. Single conidia were selected under a stereoscopic microscope $(45 \times)$, transferred with a sterile surgical needle to another Petri dish containing malt extract agar [(2\% (w/v) MEA)] medium, and incubated at $26^{\circ} \mathrm{C}$.

Single-spore isolates of $C$. pteridis (LPF059, LPF 196, LPF 201, LPF 321, LPF 417 and LPF 444) were stored in a glycerol solution $(10 \%)$ at $-80^{\circ} \mathrm{C}$. Glycerol stocks of the isolate LPF059 were grown on potato dextrose agar (PDA; Acumedia Manufacturers) medium for 10 days.

The isolates were initially identified based on morphological features (30 measurements were determined for each isolate using a Zeiss Axioscope-2 microscope at $1,000 \times$ magnification) grown on synthetic nutrient poor agar (SNA) (Nirenburg, 1981) at $26^{\circ} \mathrm{C}$, following the protocols of Lombard et al. (2009). Isolate identification was confirmed by using partial DNA sequences of the $\beta$-tubulin (tub2) and elongation factor $(t e f-1 \alpha)$ loci. These fragments of the tub2 and $t e f-1 \alpha$ gene region were amplified by using the primers and protocols described by Alfenas et al. (2013). The quality of sequences was checked by means of Sequence Scanner Software v. 1.0 (Applied Biosystems) and edited with the software package Seqman from DNAStar Inc. Sequence similarity to GenBank accessions was conducted using the Mega BLAST program. Further comparisons utilized the Calonectria polyphasic identification system available online (http://www.cbs.knaw.nl/Calonectria/BiolomicsID.asp $\mathrm{x}$ ?IdentScenario $=$ CalonectriaID) .

\section{Induction of sporulation on different culture media}

Mycelial plugs (5-mm diameter) were transferred to the center of Petri dishes containing $30 \mathrm{~mL}$ of the following culture media: PDA, oat sucrose agar (OSA; Vetec), MEA, SNA, and glucose asparagine agar (GAA), prepared as previously described (Dhingra \& Sinclair, 1995). Carnation leaf agar medium (CLA), employed in previous taxonomic studies (Crous et al., 1992), was used as a reference medium. After 10 days of incubation at $24^{\circ} \mathrm{C} \pm 4^{\circ} \mathrm{C}$, the aerial mycelium of five plates from each medium was scraped with a soft paint brush, the surface of the medium rinsed with tap water, and the colonies were submersed in tap water for $48 \mathrm{~h}$. Subsequently, the water was discarded, the excess moisture removed with gauze, and the colonies incubated in the plates with the lids off under the same laboratory conditions for $48 \mathrm{~h}$. Five plates for each medium that were not scraped (non-scraped) were used as controls. For spore quantification, conidial suspensions were prepared by adding $50 \mathrm{~mL}$ of SDW plus $0.05 \%(\mathrm{v} / \mathrm{v})$ Tween 20 to the culture surface of each treatment. Conidia were removed with a sterilized, soft paint brush, and spore concentration was determined in a Neubauer chamber. The best method for mass spore production was tested for five other C. pteridis isolates (LPF 196, LPF 201, LPF 321, LPF 417 and LPF 444).

Five plates (replicates) for each treatment (different culture media) were arranged in a completely randomized design, and the experiment was performed twice.

\section{Mycelial growth at different temperatures}

A 5-mm-diameter mycelial plug of LPF059 was transferred to the center of Petri dishes containing $30 \mathrm{~mL}$ of GAA and the plates were maintained at $5,10,15,20,25$, 30,35 or $40^{\circ} \mathrm{C}$ under a $12-\mathrm{h}$ photoperiod $\left(39 \mu \mathrm{mol} \mathrm{s}{ }^{-1} \mathrm{~m}^{-2}\right.$ fluorescent light intensity, Osram, 20W) in a completely randomized design with five replicates per temperature. The diameter of the colonies was measured daily for 10 days.

\section{Infection on Eucalyptus spp. under different light conditions}

Fully expanded excised leaves with their petioles wrapped in moistened cotton of susceptible clone 9882 (E. grandis $\times$ E. urophylla) and moderately resistant clone 6021 (E. grandis, from Rio Claro, SP, Brazil) were used in this experiment.

Aliquots of $25 \mu \mathrm{L}$ with a conidial suspension $\left(1 \times 10^{4}\right.$ conidia/mL) of LPF059 were inoculated (deposited) on the abaxial surface of each leaf, which was maintained in a plastic $11 \times 11 \times 3.5 \mathrm{~cm}$ germbox (J. Prolab) at $26^{\circ} \mathrm{C}$ under continuous light ( $39 \mu \mathrm{mol} \mathrm{s}^{-1} \mathrm{~m}^{-2}$, fluorescent light intensity, Osram, 20W) or in the dark.

The experiment was conducted in a completely randomized design with 10 replications (10 leaves) for each treatment (dark or light conditions). To obtain dark conditions, boxes were wrapped in aluminum foil. Ten leaves treated with SDW and incubated under the same conditions served as control.

The incubation period (IP) was evaluated at 6-h intervals until $50 \%$ of leaves had lesions. The percentage of leaf area with lesions was determined at $72 \mathrm{~h}$ postinoculation and was estimated by capturing images with the use of QUANT software (Vale et al., 2003).

\section{Influence of incubation temperature on Eucalyptus spp. defoliation}

To determine the influence of incubation temperature on infection of rooted cuttings, plants (Eucalyptus clone 9882) were grown in 6-L, plastic pots containing Mec Plant substrate (decomposed pine bark and vermiculite). The potted plants were fertilized weekly with $50 \mathrm{~mL}$ nutrient solution, containing $10 \mathrm{~g}$ of Ouro Verde (15:15:20 NPK) /L. After 120 days, the plants were spray inoculated with a conidial suspension $\left(1 \times 10^{4}\right.$ conidia/mL) of LPF 059 and incubated at $18,22,26,28$, and $30^{\circ} \mathrm{C}$ for $48 \mathrm{~h}$. Subsequently, 
the plants were maintained in a greenhouse $\left(25 \pm 5^{\circ} \mathrm{C}\right)$ under natural day-light photoperiod. After 50 days, the percentage of defoliation was assessed on four basal branches as previously described by Graça et al. (2009).

A completely randomized design was used, with 10 replicate inoculated plants and four non-inoculated plants as controls for each temperature tested.

\section{Data analysis}

All tests were performed independently at least twice. When no significant differences were found among the repetitions, a combined analysis of tests was conducted to compare treatments.

The statistical software Statistica (StatSoft, Inc) was used to analyze the data. Before proceeding with the analyses, data from all experiments were tested regarding the conditions of homogeneity and normality. Data from the sporulation experiment were subjected to ANOVA (analysis of variance) and treatment means were compared by using the Tukey test $(\mathrm{p} \leq 0.05)$. Data from other experiments were analyzed by using ANOVA, and regression models were chosen based on the significance of the regression coefficients using the "T" test, adopting the $5 \%$ level of probability in the determination coefficient.

\section{RESULTS}

\section{Isolation and identification of the fungal pathogen}

PCR products and resulting sequences of approximately $500 \mathrm{bp}$ were generated for the $t u b 2$ and tef$1 \alpha$ gene region. The polyphasic identification performed at the on-line Calonectria Database showed that all six isolates (LPF 059, LPF 196, LPF 201, LPF 321, LPF 417, and LPF 444) belonged to Calonectria pteridis with well-supported values of similarity (Table 1 ).

The morphology of the conidial state in culture was consistent with that of $C$. pteridis, having a stipe bearing penicillate sporulating branches, stipe extensions measuring 217-276 $\mu \mathrm{m}$, with terminal clavate vesicles 3-5 $\mu \mathrm{m}$ diam., and producing cylindrical, hyaline, uniseptate macroconidia measuring 82-98 $\mu \mathrm{m} \times 3-5 \mu \mathrm{m}$ (av. $87 \times 5 \mu \mathrm{m})$ (Figure 2).

TABLE 1 - List of Calonectria isolates, substrate, origin, and DNA sequence similarity to C. pteridis culture CBS111871

\begin{tabular}{lllc}
\hline \hline Isolates $^{1}$ & Host/substrate & \multicolumn{1}{c}{ Place } & Similarity (\%) \\
\hline LPF 059 & Eucalyptus sp. & Pará/ Brazil & 99.21 \\
LPF 196 & Eucalyptus sp. & Pará/ Brazil & 99.21 \\
LPF 201 & Eucalyptus sp. & Maranhão/Brazil & 99.11 \\
LPF 321 & Soil & Pará/ Brazil & 99.59 \\
LPF 417 & Eucalyptus sp. & Pará/ Brazil & 99.59 \\
LPF 444 & Soil & Piauí/Brazil & 99.59 \\
\hline
\end{tabular}

${ }^{1} \mathrm{LPF}$, Cultures of the "Laboratório de Patologia Florestal", DFP-UFV, Brazil.

${ }^{2}$ Similarity of partial DNA sequences of the $\beta$-tubulin $(t u b 2)$ and elongation factor $(t e f-1 \alpha)$ using polyphasic identification at on-line Calonectria Database website.

\section{Induction of sporulation on different culture media}

Because no significant difference was found between the sporulation-induction experiments $(P=0.323)$, a pooled analysis of the two independent tests was conducted. A significant interaction $(P=0.00001)$ was found among culture media and the induction method. All tested media except SNA and CLA produced more spores when the aerial mycelium was removed and the cultures were temporarily submersed in tap water. Using this method, GAA medium produced the most conidia, while SNA medium produced the least (Table 2). This was confirmed for five other isolates of C. pteridis, and significant variation in spore production was also found among these isolates (Table 3 ).

\section{Mycelial growth at different temperatures}

Mycelial growth varied significantly with temperature. The estimated optimum temperature was $24.2^{\circ} \mathrm{C}$ (Figure 3 ). At $24^{\circ} \mathrm{C}$, the colony covered the entire plate surface within 10 days of incubation. Only limited mycelial growth was obtained at $5^{\circ} \mathrm{C}$, and no growth was observed at $40^{\circ} \mathrm{C}$. However, cultures that were maintained at $40^{\circ} \mathrm{C}$ for 10 days, resumed growth when re-incubated at $25^{\circ} \mathrm{C}$, indicating that $40^{\circ} \mathrm{C}$ was not lethal .

\section{Infection on Eucalyptus spp. under different light conditions}

Significant interactions on amount of leaf infection between incubation period (IP) and lighting conditions ( $P=0.00002)$ and between IP and clones $(P=0.00062)$ were found. The time required to obtain $50 \%$ of infected leaves (IP50) was shorter for both clones tested under dark vs. continuous light conditions, and the IP50 was shorter for clone 9882 (highly susceptible) than clone 6021 (moderately resistant) under both conditions (Table 4). For both clones tested, the affected leaf area was also higher in the dark than in continuous light (Figure 4). However, no significant difference $(p \leq 0.43)$ was observed in the percentage of the affected leaf area between the two clones studied at $72 \mathrm{~h}$ post-inoculation (Figure 4).

\section{Influence of the temperature of incubation on defoliation of eucalyptus}

Defoliation of Eucalyptus spp. due to C. pteridis varied significantly with temperature (Figure 5). The estimated optimum temperature was $26^{\circ} \mathrm{C}$. No defoliation occurred on the control plants at temperatures below $30^{\circ} \mathrm{C}$. However, more than 34\% defoliation occurred on noninoculated plants at $30^{\circ} \mathrm{C}$ in both experiment replications, indicating that this high temperature could contribute to defoliation of the evaluated clones.

\section{DISCUSSION}

Sequences of the tub2 and tef- $1 \alpha$ loci and the morphological features of the anamorph allowed us to identify the fungal isolates as C. pteridis. Calonectria 

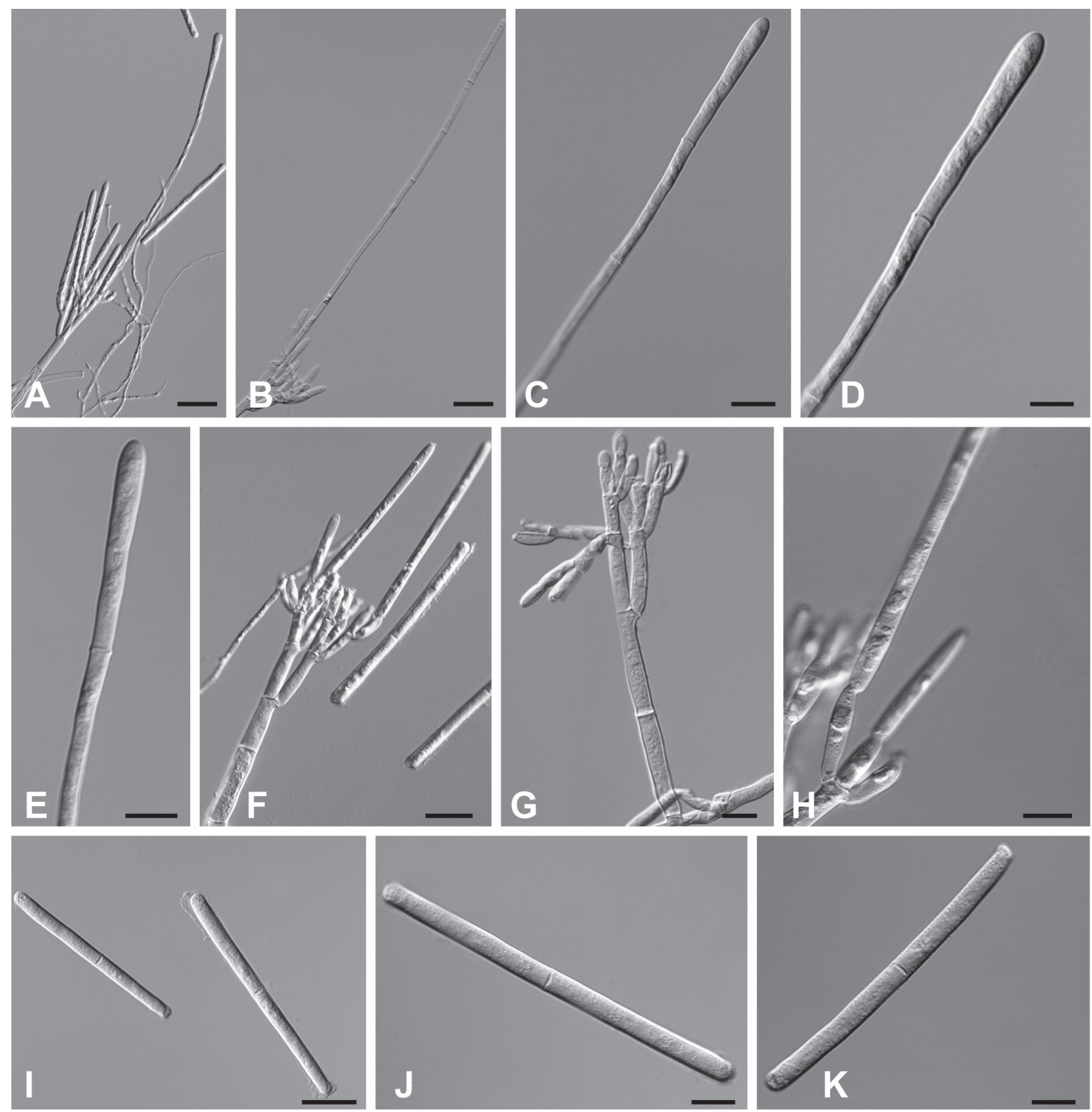

FIGURE 2 - Reproductive structures of the anamorph phase of Calonectria pteridis. A,B. Macroconidiophore containing a typical clavate vesicle. C-E. Typical clavate vesicles. F,G. Macroconidiophores. H. Phialides and I-K. Uniseptate macroconidia. Scale bars: A, B = 30 $\mu \mathrm{m} ; \mathrm{C}, \mathrm{D}, \mathrm{E}, \mathrm{G}, \mathrm{H}, \mathrm{J}, \mathrm{K}=10 \mu \mathrm{m}$; and F, I = $20 \mu \mathrm{m}$.

leaf blight, caused by $C$. pteridis, is among the most predominant foliar diseases in eucalyptus plantations and causes significant growth losses, especially in tropical and subtropical regions such as Brazil (Ferreira et al, 1995). Other species, such as C. parasiticum, C. morganii, C. ovata, C. ilicicola, and C. kyotensis, also have been associated with defoliation in eucalyptus plantations (Chen et al., 2011; Alfenas et al., 1979). Defoliation of trees reduces the photosynthetic leaf surface and consequently reduces canopy development, which can also foster increased weed competition and further decrease eucalyptus growth. Planting of genotypes that are resistant to CLB is considered the most practical method to limit CLB impacts (Crous, 2002; Alfenas et al, 2009). However, selection of resistant genotypes requires high volumes of concentrated spore suspensions. The availability of inoculum is a primary 
TABLE 2 - Conidial production of Calonectria pteridis in different culture media with and without disturbance of the mycelia in culture

\begin{tabular}{lcc}
\hline \hline Culture media $^{1}$ & $\begin{array}{c}\text { Scraped }^{\text {culture }^{2}} \\
\text { GAA }\end{array}$ & $\begin{array}{c}\text { Non-scraped } \\
\text { culture }\end{array}$ \\
\hline PDA & $18.19^{3} \mathrm{Aa}$ & $0.56 \mathrm{Ba}$ \\
OSA & $13.16 \mathrm{Ab}$ & $0.05 \mathrm{Ba}$ \\
MEA & $8.92 \mathrm{Ac}$ & $0.03 \mathrm{Ba}$ \\
CLA & $3.12 \mathrm{Ad}$ & $0.16 \mathrm{Ba}$ \\
SNA & $0.01 \mathrm{Ad}$ & $1.10 \mathrm{Aa}$ \\
\hline
\end{tabular}

${ }^{1} \mathrm{GAA}$, glucose asparagine agar; PDA, potato dextrose agar; OSA, oat sucrose agar; MEA, malt extract agar; CLA, carnation leaf agar; SNA, synthetic nutrient agar.

${ }^{2}$ Fungal cultures with mycelial scraping followed by submersion in tap water for $48 \mathrm{~h}$. Values correspond to the average number of conidia/ $\mathrm{mL}\left(\mathrm{x} 10^{4}\right)$. Means followed by the same upper case letter within each row and lower case letter in each column are not significantly different (Tukey's test, $\mathrm{p} \leq 0.05$ ).

TABLE 3 - Number of conidia (x 104) produced by different Calonectria pteridis isolates on scraped and non-scraped cultures grown on glucose asparagine agar $^{1}$

\begin{tabular}{ccc}
\hline \hline Isolate & $\begin{array}{c}\text { Scraped }^{2} \\
\text { culture }^{2}\end{array}$ & $\begin{array}{c}\text { Non-scraped } \\
\text { culture }\end{array}$ \\
\hline LPF 196 & $24.80 \mathrm{Abc}$ & $0.00 \mathrm{Bb}$ \\
LPF 201 & $54.27 \mathrm{Aa}$ & $0.12 \mathrm{Bab}$ \\
LPF 321 & $52.75 \mathrm{Aa}$ & $0.47 \mathrm{Ba}$ \\
LPF 417 & $27.27 \mathrm{Ab}$ & $0.02 \mathrm{Bab}$ \\
LPF 444 & $7.17 \mathrm{Ac}$ & $0.02 \mathrm{Bab}$ \\
LPF 059 & $59.20 \mathrm{Aa}$ & $0.02 \mathrm{Bab}$ \\
\hline
\end{tabular}

${ }^{1}$ Means followed by the same upper case letter within each row and lower case letter in column are not significantly different (Tukey's test, $\mathrm{p} \leq 0.05$ ).

${ }^{2}$ Fungal cultures with scraped mycelium following submersion in tap water for $48 \mathrm{~h}$.

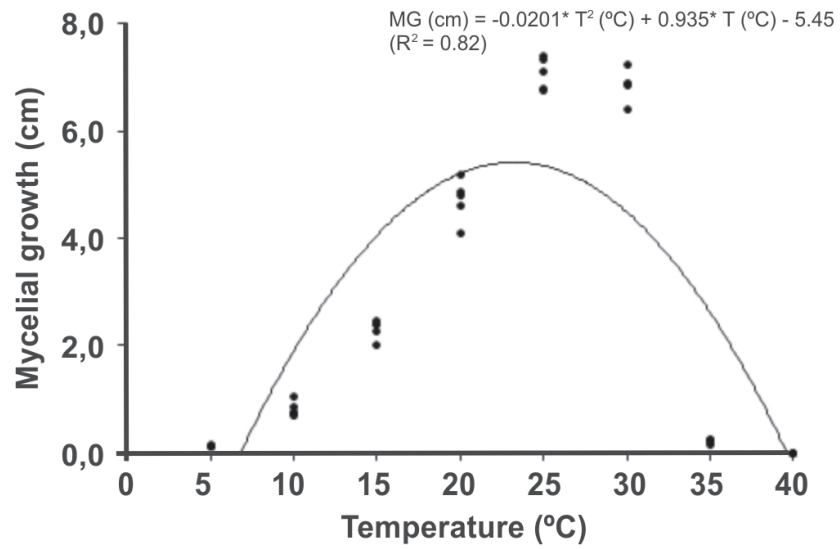

FIGURE 3 - Mycelial diameter growth of Calonectria pteridis in glucose asparagine agar medium under different temperatures, at 10 days after incubation.

Tropical Plant Pathology 38 (5) September - October 2013
TABLE 4 - Mean incubation period (IP) of Calonectria pteridis inoculated on excised leaves of two eucalyptus clones (9882 = $E$. grandis $\times E$. urophylla and $6021=E$. grandis $)$ and incubated under light or dark conditions

\begin{tabular}{ccc}
\hline \hline Clone & Condition & IP $_{\mathbf{5 0}}(\mathbf{h})^{\mathbf{1}}$ \\
\hline \multirow{2}{*}{9882} & Light & 12 \\
& Dark & 6 \\
6021 & Light & 18 \\
& Dark & 12 \\
\hline
\end{tabular}

${ }^{1}$ The time in hours required to reach $50 \%$ of disease incidence in detached leaves.

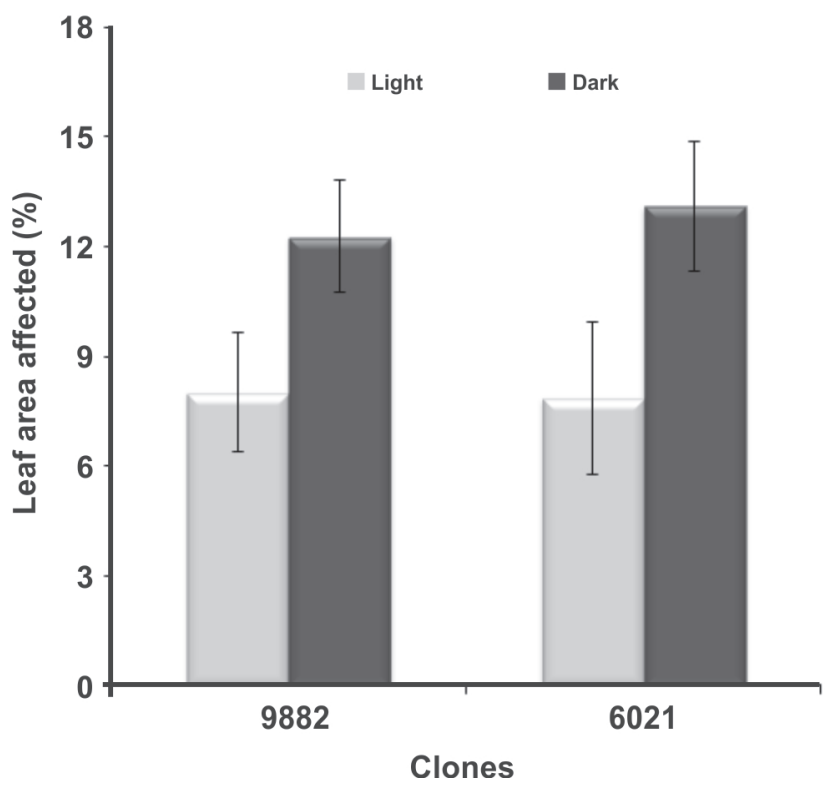

FIGURE 4 - Percentage of leaf area infected by Calonectria pteridis on two hybrid Eucalyptus clones 9882 (E. grandis $\times$ E. urophylla) and 6021 (E. grandis) incubated under light or dark conditions at 72 hours post-inoculation. Mean values of 10 replicates and the standard deviation are indicated.

limiting factor for these resistance-screening programs. Our data demonstrate that temperature plays a significant role for $C$. pteridis growth, which concurs with recent reports for other Calonectria species (Poltronieri et al., 2011; Vitale et al., 2012). Variation in spore yield on different culture media is perhaps attributable to differences in the carbon and nitrogen sources within the media tested. Barnett and Hunter (1978) studied the sporulation of several Calonectria $(=$ Cylindrocladium $)$ species in culture and observed that culture media containing organic sources of nitrogen were more favorable for sporulation than inorganic sources. According to our findings, GAA medium induced the highest spore production by $C$. pteridis. In contrast, CLA and SNA, which are the most commonly used media for morphological (shape and dimensions of vesicle, number of septa and size of conidia) and mating type studies (Crous 


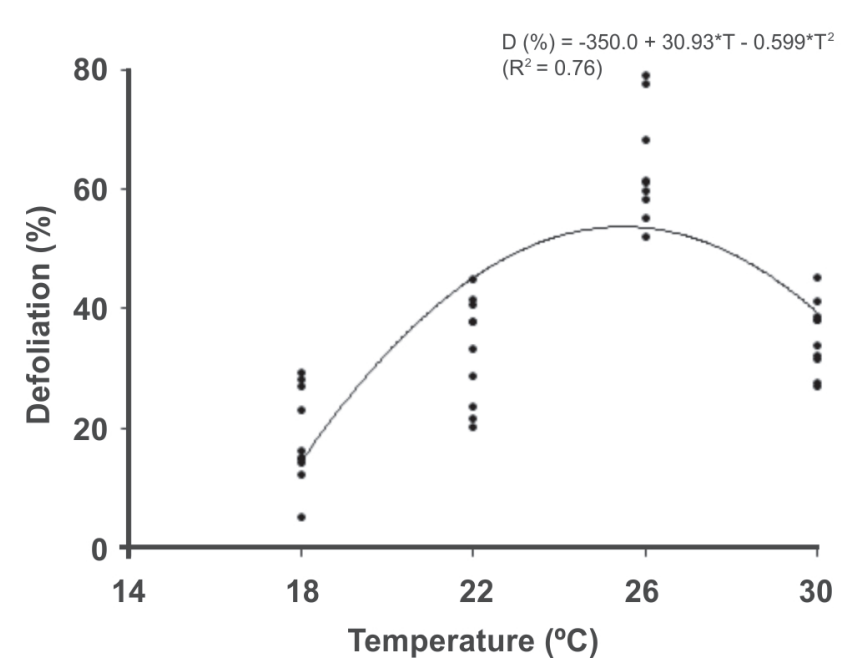

FIGURE 5 - Percentage of defoliation in the third basal branches of eucalyptus plants observed 50 days after inoculation with Calonectria pteridis.

et al., 1992; Crous et al., 1998), were not suitable for mass production of $C$. pteridis spores.

The mycelial scraping method described in this paper resulted in higher spore production than the nonscraping, independent of the isolate tested. The significantly enhanced sporulation by scraping the aerial mycelium and flooding, followed by drying and additional incubation, could be a stress-induced response or due to the elimination of potential water-soluble inhibitors of sporulation, as was previously found for Alternaria solani (Ludwig et al., 1962; Prasad et al., 1973).

Because temperature, light, and inoculum density can be quite variable under natural conditions in the field, our inoculation procedures under controlled conditions allow more precision for screening for resistance. This study demonstrates that severity of CLB caused by $C$. pteridis is significantly influenced by the temperature, which concurs with studies on other Calonectria species (Alfenas et al.,1979; Poltronieri et al., 2011). Because intraspecific variability for heat sensitivity could occur within C. pteridis, as observed with other Calonectria species (Vitale et al., 2012), further studies are needed to confirm heat-sensitivity results for diverse isolates of $C$. pteridis. Our results show that inoculated plants should be incubated for 48 hours postinoculation at approximately $26^{\circ} \mathrm{C}$ under mist-irrigation, preferably in the dark to maximize disease development according to the protocol suggested by Graça et al. (2009).

In a survey to assess the impact of Calonectria defoliation of Eucalyptus spp. in the Tucuruí-PA region in Brazil, Krügner et al. (1990) observed that CLB severity was higher during the season when the average temperature was $27.4^{\circ} \mathrm{C}$, which also reflects the estimated optimum temperature found in our studies for $C$. pteridis. In Monte Dourado-PA region of Brazil, where severe eucalyptus defoliation caused by $C$. pteridis periodically occurs (A.
Alfenas, unpublished observations), the average temperature is $26.5^{\circ} \mathrm{C}$ and average rainfall is $2.368 \mathrm{~mm}$, which are favorable conditions for development of this disease. For planting in regions with such favorable environments for Calonectria infection, Eucalyptus genotypes should be rigorously evaluated for CLB resistance under controlled conditions. This study provides essential information for optimizing mass spore production by $C$. pteridis and optimal environmental conditions for efficient CLB-resistance screening of Eucalyptus genotypes.

\section{ACKNOWLEDGMENTS}

We are grateful to Drs. Ned Klopfenstein, Amy Ross-Davis and Charles S. Hodges for critical review of the manuscript and Tonimara S. Cândido for technical assistance. We thank Jari Celulose S/A for providing partial funding for this project. This work was supported by CAPES (Coordenação de Aperfeiçoamento de Pessoal de Nível Superior), CNPq (Conselho Nacional de Desenvolvimento Científico e Tecnológico), and FAPEMIG (Fundação de Amparo à Pesquisa de Minas Gerais).

\section{REFERENCES}

Alfenas AC (1986) Fungos do gênero Cylindrocladium como patógenos florestais, no Brasil. Fitopatologia Brasileira 11:275277.

Alfenas AC, Zauza EAV, Mafia RG, Assis TF (2009) Clonagem e doenças do eucalipto. ${ }^{\text {a }}$ Ed. Viçosa MG, Brazil. Editora UFV.

Alfenas AC, Ferreira FA (1979) A mancha de folha do eucalipto no Brasil causada por três espécies de Cylindrocladium - Uma revisão da descrição da doença. Revista Árvore 3:47-56.

Alfenas AC, Matsuoka K, Ferreira FA, Hodges CS (1979) Identificação, caracteristicas culturais e patogenicidade de três espécies de Cylindrocladium isoladas de mancha de Eucalyptus spp. Fitopatologia Brasileira 4:445-459.

Alfenas RF, Pereira OL, Ferreira MA, Jorge VL, Crous PW, Alfenas AC (2013) Calonectria metrosideri, a highly aggressive pathogen causing leaf blight, root rot, and wilt of Metrosideros spp. in Brazil. Forest Pathology 43:257-265.

Chen SF, Lombard L, Roux J, Xie YJ, Wingfield MJ, Zhou XD (2011) Novel species of Calonectria associated with Eucalyptus leaf blight in Southeast China. Persoonia 26:1-12.

Crous PW (2002) Taxonomy and Pathology of Cylindrocladium (Calonectria) and Allied Genera. St Paul MN, USA. APS Press.

Crous PW, Alfenas AC, Junghans, TG (1998) Variability within Calonectria ovata and its asexual morph Cylindrocladium ovatum from Brazil. Sydowia 50:1-13.

Crous PW, Phillips AJL, Wingfield MJ (1992) Effects of cultural conditions on vesicle and conidium morphology in species of Cylindrocladium and Cylindrocladiella. Mycologia 84:497-504.

Crous PW, Wingfield MJ (1994) A monograph of Cylindrocladium, including anamorphs of Calonectria. Mycotaxon 51:341-435.

Dhingra OD, Sinclair JB (1995) Basic Plant Pathology Methods. 


\section{$2^{a}$ Ed. Boca Raton FL, USA. Lewis Publishers CRC.}

Ferreira EM, Alfenas AC, Maffia L A, Mafia RG (2006) Eficiência de fungicidas sistêmicos para o controle de Cylindrocladium candelabrum em eucalipto. Fitopatologia Brasileira 31:468-475.

Ferreira FA, Alfenas AC, Moreira AM, Demuner NL (1995) Mancha-de-pteridis: Doença foliar de eucalipto em áreas tropicais brasileiras. Fitopatologia Brasileira 20:107-110.

Graça RN, Alfenas AC, Maffia LA, Titon M, Alfenas RF, Lau D, Rocabado JMA (2009) Factors influencing infection of eucalypts by Cylindrocladium pteridis. Plant Pathology 58:971-981.

Hunter BB, Barnett HL (1978) Growth and sporulation of species and isolates of Cylindrocladium in culture. Mycologia 70:614635.

Krügner TL, Guerrini IA, Auer CG (1990) Surto epidêmico da mancha foliar causada por Cylindrocladium spp. e sua relação com o crescimento de espécies/procedências de Eucalyptus na região de Tucuruí, PA . Instituto de Pesquisas e Estudos Florestais 44:74-78.

Lombard L, Crous PW, Wingfield BD, Wingfield MJ (2010a) Phylogeny and systematics of the genus Calonectria. Studies in Mycology 66:31-69.

Lombard L, Crous PW, Wingfield BD, Wingfield MJ (2010b) Multigene phylogeny and mating tests reveal three cryptic species related to Calonectria pauciramosa. Studies in Mycology 66:1530.

Lombard L, Rodas CA, Crous PW, Wingfield BD, Wingfield MJ (2009) Cylindrocladium species associated with dying Pinus cuttings. Persoonia 23:41-47.

Ludwig RA, Richardson LT, Unwin CH (1962) A method for inducing sporulation of Alternaria solani in culture. Canadian Plant Disease Survey 42:149-150.
Nirenburg HI (1981) A simplifed method for identifyng Fusarium spp. occurring on wheat. Canadian Journal of Botany 59:15991609.

Phipps PM (1990) Control of Cylindrocladium black rot of peanut with soil fumigants having methyl isothiocyanate as the active ingredient. Plant Disease 74:438-441.

Polizzi G, Vitale A, Castello I, Groenewald JZ, Crous PW (2006) Cylindrocladium leaf spot, blight, and crown rot, new diseases of mastic tree seedlings caused by Cylindrocladium scoparium. Plant Disease 90:1110.

Poltronieri LS, Alfenas RF, Verzignassi JR, Alfenas AC, Benchimol RL, Poltronieri TPS (2011) Leaf blight and defoliation of Eugenia spp., caused by Cylindrocladium spathiphylli, and C. candelabrum in Brazil. Summa Phytopathologica 37:147-149.

Prasad B, Dutt BL, Nagaich BB (1973) Inducing sporulation in Alternaria solani $\mathrm{I}$. Effect of water treatment. Mycopathologia et Mycologia Applicata 49:141-146.

Shahin EA, Shepard JF (1979) An efficient technique for inducing profuse sporulation of Alternaria species. Phytopathology 69:618620.

Vale FXR, Fernandes Filho EI, Liberato JR (2003) QUANT. A software plant disease severity assessment. In: Proceedings of the 8th International Congress of Plant Pathology. Christchurch New Zealand. International Society for Plant Pathology. p. 105.

Vitale A, Polizzi G (2008) First record of leaf spots and stem lesions on Pistacia lentiscus caused by Cylindrocladium pauciramosum and C. scoparium in Italy. Plant Pathology 57:384.

Vitale A, Castello I, D’Emilio A, Mazzarella R, Perrone G, Epifani F, Polizzi G (2013) Short-term effects of soil solarization in suppressing Calonectria microsclerotia. Plant \& Soil 368:613617. 